\title{
Building Failure Causes in Nigeria and Mitigating Roles by Engineering Regulation and Monitoring
}

\author{
Joseph Apagu Tanko ${ }^{1}$ Felix Aromo Ilesanmi², Sunday Kilkabu Balla ${ }^{1}$ \\ ${ }^{1}$ Department of Civil Engineering, Modibbo Adama University of Technology, Yola, Nigeria \\ ${ }^{2}$ Department of Urban and Regional Planning, Modibbo Adama University of Technology, Yola, Nigeria \\ Email: hamidap01@yahoo.co.uk
}

Received October 8, 2012; revised December 11, 2012; accepted December 22, 2012

\begin{abstract}
This paper assessed some of the reported cases of building failures and their possible causes in Nigeria between 1977 and 2011. The reported major failure causes are structural failure (SF), Carelessness (CLSS), poor workmanship (PW), poor supervision (PS), poor materials (PM), and quackery (Q).These causes of failure were subjected to Chi-Square statistical test at $5 \%$ significant level and 4 degree of freedom to know the most common cause of failure in Nigeria. The analysis showed quackery as the principal culprit in the reported building failures in Nigeria with prevalence of 8 over poor supervision being the minimum in occurrence. Structural failure occurred 5 times, while poor materials, carelessness and poor workmanship occurred 4, 2 and 2 respectively. The Council for the Regulation of Engineering in Nigeria (COREN) with Engineering Regulation and Monitoring (ERM) as her arm as a technical professional group discouraging quackery and failures generally in Engineering Practice. The holistic approach needs effective training of Engineers starting with strong mathematical and scientific background at the secondary and tertiary education levels in conjunction with rigorous field and Industrial training exercises. There after effective scrutiny, professional registration process of competent engineers is followed.
\end{abstract}

Keywords: Building Failures; Mitigation Roles; Registration; Practice; Regulation of Engineering

\section{Introduction}

The term Engineer denotes a certified person by Council for the Regulation of Engineering in Nigeria (COREN) that has received professional training in pure and applied sciences and adequate field/Industrial training [1]. However, the name Engineer has often been misused without obtaining the necessary qualifications which has often resulted in consequences on engineering structures and services. Indiscriminate engineering structures and services failures has characterised our generation because proper assessment of value engineering and its effective implementation is lacking in the building industry in Nigeria as observed by [2]. Engineering failure may refer to service or structural failure of designed structures like machines, incessant electric power outrages, road failures, dam failures, boreholes, bridges, buildings, material failures, etc.

The financial and lives lost due to any engineering failure is an important attraction to the society, however, cost effective designed engineering product which is convenient to use and with guaranteed safety of the hitherto trusted engineering profession is being eroded gradually. Random sampling of some of these engineering structures/products designed and constructed by quacks would convince any casual observer that it would be preferable to have stability tests before using them for fear of possible failure. Typical examples are the failure of buildings either during or after construction being experienced regularly in our societies, incessant electric power outrages, water supply system failure, culverts, and drainages, etc. The Nigerian Engineer is undoubtedly credible but quacks have infiltrated this noble profession at all stages from design, construction and maintenance stages of the engineering structures and services as observed by [3].

A quack was defined [4] as a person who dishonestly claims to have special knowledge and practising a skill he/she does not have. A quack is an impostor, fake, fraud, pretender, swindler, and a counterfeit person. There is no doubt that there are many quacks in the Nigerian labour market today. The number of houses designed and supervised by professionally unqualified architects and structural Engineers in Nigeria cannot be counted for number. There are quacks in almost all fields of human endeavour but the fewer they are, the less the fear of professional adulteration and the better a society would be. It behoves good professional practice therefore to discourage quackery in all its form. Quacks cannot but be 
mentioned as possible culprits in the event of any massive professional malpractice anywhere in the world. The training institutions, law enforcement agencies, labour markets, etc. have their contributions to the incidence of quack multiplication especially in Nigeria.

Although all disciplines have their professional regulatory bodies in Nigeria, COREN through the Engineering Regulation and Monitoring (ERM), backed by Decrees 55 of 1970 and 27 of 1992 (Amendment) stipulated the following objectives amongst others [5].

- Ensure that Engineering is practiced in Nigeria in accordance with relevant Codes of Engineering practice, in the interest of Public safety, and for the protection of her development and economic investment;

- To enforce maintenance of discipline and strict standards of ethics in the practice of Engineering profession in Nigeria;

- To foster speedy acquisition of all relevant Engineering and Technological skills by Nigerians, required to accelerate development efforts and effect speedy modernisation of Nigeria;

- To minimize and with time, eliminate Engineering and Technological dependence of Nigeria on other countries;

- To minimise the enormous foreign exchange leakage from Nigeria, resulting from existing domination of Engineering activities, particularly in the petroleum and construction sectors of the economy by foreigners;

- To facilitate and expedite the positioning of the Nigerian Engineering family to join in the global competition for incomes accruable to Nigeria from International Engineering Consultancy and Construction practice; and

- To monitor and enforce compliance with Decree 55 of 1970 as amended by Decree 27 of 1992, by all practitioners of Engineering in Nigeria.

Achieving the above objectives by COREN would have made giant strides in reducing quackery and engineering failures in Nigerian society. If this paper will assist in creating the necessary ripple to make all the stake holders adopt a policy that would reduce to the barest minimum the ever increasing number of quacks in Nigeria, then the aim of the paper would have been achieve.

Holistic approach to discourage quackery therefore, entails that COREN, the Training Institutions and Government should make policies that would encourage easy training up of professionals to the required level as suggested by [6]. Such policy should discourage professionals that tend to claim abilities of closely related but different professions without acquiring the necessary training as to provide the right calibre of Technical workforce for the Nigerian society. The following main branches of engineering were enumerated by [7], most of which are very familiar in the Nigerian context that includes Agricultural, Chemical, Civil, Electrical and Electronics, and Mechanical Engineering however, an engineer who works in any of the engineering related fields usually requires a basic knowledge of the other engineering fields because most engineering problems are complex and interrelated. It was also noted by [6] that besides the principal branches, engineering includes many more specialties like acoustical, architectural, automotive, ceramic, transportation, and textile engineering. It was stated by [1] that she caters for about 65 engineering disciplines. The complexity of these interrelated disciplines has given room for quacks to breed especially in the Nigerian society where majority of the people are caught in a vicious circle of ignorance, poverty and diseases. In consequence, several spectacular building failures in Nigeria are reported in Table 1.

\section{Materials and Methods}

The reported causes of building failure in Table $\mathbf{1}$ that include Faulty Design (FD), Poor Design (PD), Overloading (OL), Rainstorm (RS), No Structural Design (NSD), Faulty Design Implementation (FDI), Unauthorised Conversion to Storey Building (UCSB), and NonCompliance with approved building plan (NC) were all considered to be due to quackery as shown in Table 2.

The failure types were also assumed to occur in any State or City in Nigeria that is considered as uniformly distributed event. However, if this hypothesis proves contrary, then analysis will be based on prevalence.

The summary of building failures and their causes in Nigeria is shown in Table 3.

Chi-Square goodness of fit test was applied to the data in Table 3 to test the hypothesis of uniform distribution of failure causes. The null hypothesis was rejected at 5\% level of significance thus giving way for assessing the data based on prevalence.

\section{Results and Discussions}

In Table 3, structural failure (SF) occurred about 5 times the value of poor supervision being the minimum. Similarly, carelessness (CLSS), poor workmanship (PW), poor materials (PM) and quackery (Q) occurred 2, 2, 4 and 8 times respectively. The corresponding expected values for structural failure (SF), carelessness (CLSS), poor workmanship (PW), poor supervision (PS), poor materials (PM) and quackery (Q) are 48, 15, 15, 9, 33, and 78 respectively.

The Chi-Square value was computed as 88 .

The tabulated Chi-square value at $5 \%$ significance level and 4 degree of freedom is 9.488 , while the Tabulated Chi-square value at $1 \%$ significance level and 4 degree of freedom is 13.277 . 
Table 1. The reported cases of building failures and their causes for the period 1974-2011 in Nigeria.

\begin{tabular}{|c|c|c|c|c|c|}
\hline $\mathrm{S} / \mathbf{N}$ & Building Type & Location & Collapsed in & Cause(s) & Lives Lost \\
\hline 1 & Multi-storey (UB) & Ibadan, Oyo & 1974 & OL/SF/Q & 27 \\
\hline 2 & Hostel Building & O.A.U. Oyo & 1976 & SF & Nil \\
\hline 3 & Residential Building & Barnawa, Kaduna & 1977 & $\mathrm{FD} / \mathrm{Q}$ & 28 \\
\hline 4 & School Building & Makarfi, Kaduna & 1977 & CLSS & 7 \\
\hline 5 & 3-Storey RB & Barnawa, Kaduna & 1980 & $\mathrm{FD} / \mathrm{Q}$ & 6 \\
\hline 6 & K/Hyatt Regency & Lagos & 1981 & $\mathrm{OL} / \mathrm{Q}$ & 113 \\
\hline 7 & Storey RB & Allin, Ikeja, Lagos & 1985 & $\mathrm{OL} / \mathrm{Q}$ & Nil \\
\hline 8 & Residential Building & Adeniji Adele, Lagos & 1985 & $\mathrm{OL} / \mathrm{Q}$ & 2 \\
\hline 9 & Residential Building & Ojuelegba, Lagos & 1985 & RS & Nil \\
\hline 10 & 4 Storey RB (UB) & Iponri, Lagos & 1985 & SF & 13 \\
\hline 11 & Residential Building & V/Island, Lagos & 1985 & $\mathrm{OL} / \mathrm{Q}$ & 13 \\
\hline 12 & Residential Building & Gboko, Benue & 1985 & CLSS & 1 \\
\hline 13 & Residential Building & A/Avenue, Lagos & 1985 & CLSS & Nil \\
\hline 14 & Residential Building & Adeniji Adele Lagos & 1985 & $\mathrm{FD} / \mathrm{Q}$ & 2 \\
\hline 15 & High Court Building & Imo State & 1986 & SF & 2 \\
\hline 16 & Mosque Building & Oshogbo, Osun & 1986 & SF & 2 \\
\hline 17 & Residential Building & Ona Street, Enugu & 1986 & NI & 2 \\
\hline 18 & 2 Storey Building (UC) & Agege, Lagos & 1987 & SF & 2 \\
\hline 19 & Residential Building & Idumota, Lagos & 1987 & NSD/Q & 17 \\
\hline 20 & Commercial Building & Ikorodu Rd, Lagos & 1987 & CLSS & 4 \\
\hline 21 & Residential Building & Calabar, C/River & 1987 & CLSS & 3 \\
\hline 22 & 6-Storey Building & Mende Lagos & 1987 & $\mathrm{FD} / \mathrm{Q}$ & Nill \\
\hline 23 & School Building & Port Hacourt, Rivers & 1990 & NSD/Q & Nill \\
\hline 24 & 6-Storey hotel complex & Maryland, Lagos & 1993 & SF & Not Known \\
\hline 25 & Sports Complex, Storey & Area 10, Abuja & 1993 & PW & NR \\
\hline 26 & MS-SHB Nicon-Noga & Karo, Abuja & 1993 & $\mathrm{Q}$ & NR \\
\hline 27 & MB (UC) & Abeokuta, Ogun & 1995 & $\mathrm{Q}$ & 2 \\
\hline 28 & Storey Building (UC) & Central Lagos & 1995 & PW & 10 \\
\hline 29 & 3-Storey CB & Lagos & 1995 & SF & 6 \\
\hline 30 & School building & Ibadan, Oyo & 1995 & PW & Nill \\
\hline 31 & Storey building & Ibadan, Oyo & 1995 & SF & 6 \\
\hline 32 & UCSB, CB (UC) & Oshodi, Lagos & 1996 & UCSB/Q & 7 \\
\hline 33 & SB (UB) & Lagos State & 1996 & SF & Injury only \\
\hline 34 & 6-Storey (UB) & Lagos State & 1996 & $\mathrm{Q}$ & 1 \\
\hline 35 & 2 Storey building & Mushin, Lagos & 1997 & PM & Nill \\
\hline 36 & Duplex building & Gwarinpa, Abuja & 1998 & SF & 2 \\
\hline 37 & 3 storey RB & Ibadan, Oyo & 1998 & $\mathrm{FD} / \mathrm{Q}$ & Several \\
\hline 38 & 4 Storey CB (UC) & Akure, Ondo & 1998 & PS & 8 \\
\hline 39 & 2 Storey RB & Abeokuta, Ogun & 1998 & PM & Nill \\
\hline 40 & 3-Storey RB & Surulere Lagos & 1999 & $\mathrm{PM}$ & 4 \\
\hline 41 & 1 Storey RB & V/Island, Lagos & 1999 & $\mathrm{RS} / \mathrm{Q}$ & NR \\
\hline 42 & 3 Storey RB & Oko-Oba, Lagos & 1999 & SF & Nill \\
\hline 43 & 3 Storey RB & CB, Abuja & 1999 & FDI/Q & NA \\
\hline 44 & 1 Storey RB & Agege, Lagos & 1999 & SF & Nill \\
\hline 45 & 3 Storey RB & Iju-isaga, Lagos & 1999 & $\mathrm{RS} / \mathrm{Q}$ & 35 \\
\hline 46 & 2 Storey RB & Ifo, Ogun & 1999 & $\mathrm{RS} / \mathrm{Q}$ & 20 \\
\hline 47 & STOREY RB & Mushin, Lagos & 2000 & $\mathrm{FD} / \mathrm{Q}$ & NA \\
\hline 48 & Estate Building & Lekki Rd, Lagos & 2000 & SF & Nill \\
\hline
\end{tabular}


Continued

\begin{tabular}{|c|c|c|c|c|c|}
\hline 49 & 2 Storey MB & Mushin, Lagos & 2001 & $\mathrm{UCSB} / \mathrm{Q}$ & 7 \\
\hline 50 & 1-Storey RB (UC) & Iwoye-Ijesa, Osun & 2001 & SF & 7 \\
\hline 51 & Multi-storey CRB & Ebute-Meta, Lagos & 2007 & $\mathrm{UCSB} / \mathrm{PS} / \mathrm{PM} / \mathrm{Q}$ & Several \\
\hline 52 & Multi-storey Building & Kano & 2007 & $\mathrm{FD} / \mathrm{Q}$ & Several \\
\hline 53 & PB Nurs./Prim. Sch. & Ibadan, Oyo & 2008 & PM & 13 \\
\hline 54 & 5 Storey PB (UB) & Wuse Area, Abuja & 2008 & PW & 2-I, 100-T \\
\hline 55 & 2 Storey RB (UC) & Abeokuta, Ogun & 2008 & NC/PM & 2 \\
\hline 56 & 6 Storey LATH (UB) & Ogbomoso, Oyo & 2009 & $\mathrm{PM} / \mathrm{PS} / \mathrm{PW}$ & 5 \\
\hline 57 & A Wall FENCE & GRA, Enugu & 2009 & NPD/Q & 1 \\
\hline 58 & Uncompleted Building & Itamorin, Abeokuta, Ogun & 2009 & $\mathrm{PM} / \mathrm{HC}$ & 3, 11-I \\
\hline 59 & Building (UC) & Oshodi Lagos & 2010 & PM & 4, 12-I \\
\hline 60 & Storey Building (UB) & V/Island, Lagos & 2010 & $\mathrm{PM} / \mathrm{NC} / \mathrm{WS}$ & 1, 2-I \\
\hline 61 & 4 Storey UB & Abuja & 2010 & $\mathrm{PM} / \mathrm{NC}$ & 23, 11-I \\
\hline 62 & 4 Storey Building & V/Island, Lagos & 2010 & $\mathrm{OL} / \mathrm{Q}$ & 3 \\
\hline 63 & 2-Storey Building & Mararaba, Nasarawa & 2011 & SF & 2, 9-I \\
\hline 64 & 5-Storey Building & Ikeja, Lagos & 2011 & SF & NR \\
\hline
\end{tabular}

Source: [8]. Where, FD—Faulty design; PD—Poor design; PW—Poor workmanship; PS—Poor supervision; PM—Poor materials; RS—Rainstorm; SFStructural failure; UCSB - Unauthorised conversion to storey building; WC-Weak concrete; FDI-Faulty design Implementation; HC—Hasty construction; NC—Non Compliance with approved plans; NSD—No structural design; NI—Not Investigated; NPD—No proper drainage; OL—Over loading; Q—Quackery; CLSS-Carelessness; I-Injury only; NR-Not recorded.

Table 2. Reported collapsed buildings and deaths according to states in Nigeria 1974-2011.

\begin{tabular}{cccccc}
\hline S/N & States & Deaths & Failures & DPF & Remarks \\
\hline 1 & Abuja (FCT) & 27 & 4 & 6 & PW, Q, SF, Q, PW, PM/NC \\
2 & Benue & 1 & 1 & 1 & CLSS \\
3 & Cross River & 3 & 1 & 3 & CLSS \\
4 & Enugu & 3 & 2 & 2 & NI, Q \\
5 & Imo & 2 & 1 & 2 & SF, Q \\
6 & Kaduna & 41 & 3 & 14 & Q, Q, CLSS \\
7 & Kano & Several & 1 & Nil & PM \\
8 & Lagos & 132 & 32 & 4 & Q, Q, Q, Q, SF, Q, CLSS, SF, Q, CLSS, Q, SF, SF, UCSB, SF, Q, M, PM, Q, SF, SF, Q, Q, SF, Q, \\
9 & Nasarawa & 2 & 1 & 2 & Q, PM, PM/NC/WS, Q, SF \\
10 & Ogun & 27 & 5 & 6 & SF \\
11 & Ondo & 8 & 1 & 8 & Q, PM, Q, Q, PM \\
12 & Osun & 11 & 3 & 4 & PS \\
13 & Oyo & 38 & 7 & 8 & SF, SF, Q \\
14 & Rivers & - & 1 & - & PM, PW, PM/CLSS, Q, SF, PW, Q \\
\hline
\end{tabular}

Table 3. The summary of reported building failure and their causes in Nigeria.

\begin{tabular}{cccc}
\hline Failure Causes & Frequency of Failure & Prevalence & Expected \\
\hline Structural Failure (SF) & 16 & 05 & 48 \\
Carelessness (CLSS) & 05 & 02 & 15 \\
Poor Workmanship (PW) & 05 & 02 & 15 \\
Poor Supervision (PS) & 03 & 01 & 09 \\
Poor Materials (PM) & 11 & 04 & 33 \\
Quackery (Q) & 26 & 08 & 78 \\
\hline
\end{tabular}


Since the Chi-square calculated value of 88 is greater than Chi-square actual (tabulated) of 9.488, it means statistically, that the earlier assumed hypothesis that the reported causes of building failure in Nigeria can happen anywhere or uniformly distributed should be rejected.

With this statistical result, the reported cases of building failures in Nigeria are majorly caused by quackery which had prevalence of 8 over poor supervision being the minimum in occurrence. This was followed by structural failure that occurred 5 times. Poor materials occurred 4 times while carelessness, poor workmanship occurred 2 times each.

Quackery being the major cause of building failures in Nigeria multiplies under the following conditions:

1) A few professionals than required to meet up professional requirements in the respective disciplines resulting in too many technical jobs to be handled by very few professionals. This gives room for unqualified individual's or quacks to take up the challenge of doing what professionals ought to have done.

2) Too many graduates in engineering that are unregisterable leaving many of them practicing without registration permit.

3) When unemployment ravages a particular profession, quacks may be bred as professionals in attempts to do the work of other professions where the economic climate is more favourable.

4) Difficulty in getting professional registration could lead to the multiplication of quacks because some professions make it extremely difficult for qualified new entrants to get into the professional clique and grow.

Poor training facilities exist in most of the training institutions thereby increasing the incidences of quackery in Nigerian labour markets. Although some Polytechnics and Universities in Nigeria have accredited most of their programmes, others are with denied or no accreditation. The products of unaccredited institutions are poorly trained, become quacks in the system and may not be able to pass the test of certification at the professional registration point. This can reduce the number of professionals in the labour market. In the same way when there are too few professionals to handle professional tasks, quacks come on board.

The polytechnics aid in the multiplication of quacks in Nigeria through the following:

- Polytechnic products are in the quest for white-collar jobs just like their University counterparts;

- Polytechnic products do not want to accept the role of middle-level manpower; thereby leaving the works of middle level manpower to the Trade Centres and Technical College's products as well as artisans and roadside workers.

- Polytechnic products have no specialized skills in specific trades of their professions but most at times claim to know all specialisations in their profession; - Opportunities of advancement in training to professional levels have been made difficult or impossible especially for diploma holders and as a result are left in the labour market as quacks;

- Inability to stay under the professionals (superiority and inferiority complexes).

The Universities on the other hand contribute to the pool of quacks in Nigeria in many ways especially their programmes which give them more opportunities to get to the level of being professionally qualified Engineers. University products that have not been registered but practicing engineering are quacks as well those not registered because of deficiency in programmes undertaken. Graduates that scored low grades while in school; those who failed professional examinations; those who were de-registered because they could not abide by the rules of the profession; University dropouts; Products of unaccredited programmes; and those not in that particular discipline or profession contribute the quacks in the labour market.

Thus educational planners and administrators especially in the Engineering disciplines should block all the loop holes so that quacks could be reduced in the engineering professions. Having considered the reality of quackery in the practice of Engineering in Nigeria and the danger the nation is being so exposed to, all stakeholders should find specific roles to play as to put right the wrong. Specific remedial roles that the Nigerian Universities, Polytechnics, Colleges of Technology and ERM can play may include the following:

1) Run approved and accredited programmes that meet the National Universities Minimum Standard [9] only;

2) Admit qualified candidates for programs only;

3) Provide qualitative training and retraining for the staff and the students;

4) Provide facilities and conducive learning environment for the students;

5) Insist and assist staff to be professionally registered;

6) Lead the products to attain professional recognition; and;

7) Create a forum for engineering educators to be trained and retrained.

The ERM Inspectors are charged with visiting engineering establishments allied to engineering in both private and public sectors for collection of data using questionnaires as:

- To obtain data on Companies active in engineering practice in Nigeria;

- To ascertain their compliance with Nigerian laws pertaining to the Engineering in the country;

- To establish adherence to Codes of Ethics and practice of Engineering in Nigeria, in the Public and national interest; 
- To obtain manpower and technological data for Economic and Social Engineering Planning; and

- To establish the basis for imposition of sanctions against defaulters in compliance with Engineering Laws and Regulations in Nigeria.

Self-searching is required by each of the Nigerian Universities, Polytechnics and Colleges of Technology on each of the areas itemised above. Without specific commitment either in terms of staffing, training or provision of the much needed training facilities, the Universities, Polytechnics and Colleges of Technologies are bound to continue producing quacks. Effective Education policies should be implemented judiciously for qualitative education at all the levels and for all disciplines as stipulated by [10].

\section{Conclusions}

Quackery has being identified as the major cause of building failure in Nigeria based on the reported cases of building failure and their causes for the period 1974 to 2011. The reduction of quacks in the Nigerian labour force is a major issue. The stake holders (educational training, industries, and professional practice regulating agencies, law enforcement agencies and policy makers) all have very important roles to play. With professionally sound engineers in our labour markets, the fewer houses, bridges, dams, etc., will collapse and the fewer potholes on our roads, the fewer obstructions on the streets and fewer problems will be experienced in our systems.

To achieve less infrastructural problems in the society, all the stake holders have to tackle the problems holistically. This starts with training by capable personnel with effective equipment in secondary and tertiary Institutions. This is then backed by industrial training for a reasonable period and professional registration.

\section{Recommendations}

The following areas are advanced to be explored for the reduction of quacks in the engineering disciplines in particular and in the entire educational system in general.

- Engineers and architects can learn much from previous cases of failures by making COREN repository centers. The ERM may be equipped and made effective and capable of keeping such pieces of information and make them available for the reading audience. This will be similar to the Architecture and Engineering Performance Information Center set up at the University of Maryland in July 1982. These repository centers should collaborate with bodies like the Nigerian Building and Roads Research Institute (NBRRI) for areas of common interest.

- There should be qualitative education for our students to allow them appreciate the demands of each level of education.

- Amplification of the benefits of Polytechnic education as the actual wheel of progress in technological development will assist in the elimination of the inferiority complex on middle-level manpower.

- Proper orientation of the University and Polytechnic teachers to train their students in entrepreneurship studies that would make effective contributions to national development.

- Increasing product development courses that are relevant to each profession.

- Diversifying the roles of Universities of Technology in technological education development.

- Tasking of specific Universities of Technologies and Polytechnic programmes by governments, institutions, industrialists to develop specific products to meet the need of the population.

- The nation should explore the pros and cons of parallel professional bodies for the two systems of education. If it seems advantageous, it should be adopted without delay with responsibilities assigned to each.

- Accreditation of all diploma awarding institutions especially consultancy services programmes of Universities and non-polytechnics. Unaccredited programmes should not be allowed to run any further in any system of education in Nigeria.

- Adequate general studies courses for the diploma graduates to make them compete favourably with their University counterparts.

\section{REFERENCES}

[1] COREN, "Programme of Events for the 14th Engineering Assembly Held on 20th \& 21st September 2005 at the International Conference Centre," Council for Regulation of Engineering in Nigeria, Abuja.

[2] S. K. Balla, “Assessment of Value Engineering Implementation in Building and Construction Industry in Nigeria,” Unpublished M.Sc. Construction Management, Federal University of Technology, Yola, 2008.

[3] F. A. Ilesanmi, "Polytechnic Education Response to Quacks Multiplication in the Nigerian Environmental Sciences Disciplines," Paper Presented at the Second National Conference of the Academic Staff Union of Polytechnics (ASUP), The Federal Polytechnic, Nasarawa, 10 July 2003.

[4] Gazette, "The COREN Engineering Regulation Monitoring Programme (ERMP),” Official Gazette, Vol. 26, No. 86, 1985, pp. 338-339.

[5] F. A. Ilesanmi, "Problems of Further Education in Nigeria," Paper presented at the Seminar on Critical Issues on Technical Education in Nigeria at the Institute of Education, University of Jos, Jos, 1991.

[6] H. Stark, “Engineering in Microsoft ${ }^{\circledR}$ Encarta ${ }^{\circledR}$ Encyclopedia 2003,” ${ }^{\circledR}$ 1993-2002 Microsoft Corporation.

[7] S. P. Ejeh, "Building Collapse Phenomenon in Nigeria: 
The Role of Nigerian Building and Road Research Institute (NBRRI)," Proceedings of NBRRI Stakeholders' Forum, Abuja, 24-25 May 2011, pp. 67-98.

[8] NUC (National Universities Commission), “Approved Minimum Academic Standards,” National Universities Commission, Lagos, 1989.
[9] P. Procter, "Longman Dictionary of Contemporary English,” Longman Group Limited, Essex, 1981.

[10] Federal Republic of Nigeria, "The Nigerian Policy on Education,” Federal Ministry of Education, Lagos, 1979. 